\title{
EFFECT, IMMOBILIZATION AND COOPERATIVITY OF AMENDMENTS ON REMEDIATION OF PB-CONTAMINATED SOIL
}

\author{
ChAng, J. H. ${ }^{1,2 \#}-$ LiU, Q. F. ${ }^{1,2 \#}-$ YU, J. ${ }^{1,2, *}-$ WANG, Y. T. ${ }^{3}-$ PENG, W. D. ${ }^{1,2}-$ CHEN, J. Y. ${ }^{1,2}$ \\ - LIU, W. ${ }^{4}$ \\ ${ }^{I}$ Department of Environmental Science and Engineering, College of Architecture and \\ Environment, Sichuan University, Chengdu 610065, China \\ ${ }^{2}$ Institute of New Energy and Low Carbon Technology, Sichuan University, Chengdu \\ 610065, China \\ ${ }^{3}$ Chengdu Academy of Environmental Sciences, Chengdu 610072, China \\ ${ }^{4}$ Chengdu Hydrogeological Engineering Geological Center, Chengdu 610081, China \\ ${ }^{\#}$ These authors contributed equally to this work and should be regard as co-first authors \\ *Corresponding author \\ e-mail: yuj@scu.edu.cn; phone: +86-189-8093-9168
}

(Received $1^{\text {st }}$ Mar 2019; accepted $21^{\text {st }}$ May 2019)

\begin{abstract}
In our study, zeolite, sepiolite, vermiculite and biochar were added to high-concentration lead-contaminated soils, respectively, and the metal fractions, toxicity leaching amount and leaching characteristics of lead $(\mathrm{Pb})$ in soils were studied after $30 \mathrm{~d}$. Besides, the feasibility of chemical immobilization to reduce $\mathrm{Pb}$ was investigated. In the soil immobilization experiments, compared with the control, the toxicity leaching amount of soils added zeolite, sepiolite, vermiculite and biochar decreased. The decreasing ratios were $40.12 \%, 41.28 \%, 25.50 \%$, and $16.04 \%$, respectively. It is clear that the treatment of zeolite showed the best effect. And the group matching curing agents (GMCAs) with a mass ratio of 2:1 for zeolite and sepiolite was the best, of which the $\mathrm{Pb}$ content in soil leaching solutions decreased by $41.4 \%$. Meanwhile, through soil column leaching experiment, compared with the control, the $\mathrm{pH}$ of leachates generally increased, and the electrical conductivity (EC) of leachates presented a falling trend. The $\mathrm{Pb}$ content of accumulated leachates from treatments decreased, and the best effect treatment was at a mass ratio of 1:2 for zeolite andsepiolite with the highest decrease rate at $93.35 \%$. And the immobilization effect was further verified. Therefore, the addition of curing agents could decrease the bioavailability and migration of $\mathrm{Pb}$.
\end{abstract}

Keywords: lead contamination, curing agents, stabilization, soil leaching column, environmental assessment

\section{Introduction}

With the advancement of industrial and agricultural modernization, soil heavy metal contamination has become an extremely important and serious global environmental problem in recent decades (Liu et al., 2014). $\mathrm{Pb}$ is a common heavy mental pollutant owning to the fact that excessive intake of $\mathrm{Pb}$ can damage nerve and human organs such as kidney and liver, increasing the risk of cancer (Taylor et al., 2014; Cao et al., 2015; Schwab et al., 2005). Pb can easily be complexed with soil colloids and adsorbed on oxides and clays because of its hard degradation, limited soluble and chronicity in soils (Suman et al., 2005; Putra et al., 2013). In 
recent decades, due to the industrial pollution caused by human activities such as electroplating, atmospheric deposition from combustion of leaded gasoline, metal smelting and coal mining, $\mathrm{Pb}$ concentration in soil has increased dramatically (Tai et al., 2013). Consequently, it is urgent to develop a method for the remediation of $\mathrm{Pb}$-contaminated soils.

At present, the remediation methods of $\mathrm{Pb}$-contaminated soils mainly focus on soil washing, electrodialysis and phytoremediation due to their outstanding effects (Amrate et al., 2005; Gupta et al., 2013; Xu et al., 2014; Suzuki et al., 2014). Although these methods may be effective to remediate $\mathrm{Pb}$-contaminated soils, they usually tend to be expensive and time-consuming (Suman et al., 2005). On the contrary, immobilization as a main potential soil remediation technique has received considerable attention (Hwang et al., 2008; Kumpiene et al., 2008).

The immobilization of heavy mental is a remediation technique applied to decrease the mobility of elements by adding curing agents in soils, so that reducing the bioavailability and solubility of heavy metals (Mcgowen et al., 2001; Mignardi et al., 2012). Soil immobilization technique has been successfully applied to radioactive waste, sediment, and industrial sludge. Compared with other technologies, this technology can be applied widely and the processing time is short. Curing agents have different curing mechanism for heavy metals, such as soil $\mathrm{pH}$, ions exchange, adsorption, coordinating action, co-precipitation, etc. (Suman et al., 2005). However, most studies on heavy metal immobilization treatments aimed at single curing agent remediation, rarely considering GMCAs remediation or verifying further immobilization effect by soil column leaching experiment.

Therefore, this study on batch immobilization experiments and soil column leaching experiment were conducted by selecting four kinds of curing agents, including zeolite, sepiolite, vermiculite and biochar. The purposes of the study were:(1) to compare immobilization effects of different curing agents on $\mathrm{Pb}$ contaminated soils so that screening out the feasible curing agents; (2) to study the leaching characteristics and the rules of migration and transformation of $\mathrm{Pb}$ contaminated soils under different treatments, and to assess the influence of the soils on the surrounding environment after immobilization.

\section{Materials and methods}

\section{Soil sample and curing agents}

The topsoil layer $(0-20 \mathrm{~cm})$ of the tested soil was collected from one battery

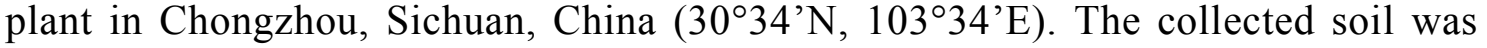
dried at room temperature, and then the uniform soils were obtained through a 2 $\mathrm{mm}$ nylon mesh. Zeolite, sepiolite, vermiculite and biochar were used in the immobilization experiment. Zeolite is an artificial zeolite. Sepiolite particle diameter is $\leq 74 \mathrm{um}$. Vermiculite particle size is $0.5 \sim 1.5 \mathrm{~mm}, 12 \mathrm{~h}$ after soaking by $7.5 \%$ potassium nitrate solution at $600 \sim 800{ }^{\circ} \mathrm{C}$ heating 5 to $7 \mathrm{~min}$, and then through 100 mesh. Biochar particle size is less than 150 microns to corn starch and coconut shell as raw material, under the environment of low oxygen content at $600{ }^{\circ} \mathrm{C}$ high temperature pyrolysis, and then through 100 mesh. All reagents obtained as chemical pure were used in the study. All the solutions were prepared by deionized water. The physical and chemical properties of soil are shown in Table 1. 
Table 1. Physical and chemical properties of the tested soil

\begin{tabular}{c|c|c|c|c|c|c|c|c}
\hline $\mathbf{p H}$ & $\begin{array}{c}\text { Organic } \\
\text { matter } \\
\mathbf{g} / \mathbf{k g}\end{array}$ & $\begin{array}{c}\text { Total } \\
\text { phosphorus } \\
\mathbf{m g} / \mathbf{k g}\end{array}$ & $\begin{array}{c}\text { Cation exchange } \\
\text { capacity } \\
\mathbf{c m o l} / \mathbf{k g}\end{array}$ & $\begin{array}{c}\text { Total } \\
\text { nitrogen } \\
\mathbf{m g} / \mathbf{k g}\end{array}$ & $\begin{array}{c}\text { Pb } \\
\text { concentration } \\
\mathbf{m g} / \mathbf{k g}\end{array}$ & $\begin{array}{c}\text { Silt } \\
\mathbf{\%}\end{array}$ & $\begin{array}{c}\text { Clay } \\
\boldsymbol{\%}\end{array}$ & $\begin{array}{c}\text { Sand } \\
\mathbf{\%}\end{array}$ \\
\hline 6.71 & 18.2 & 465.6 & 7.23 & 910.8 & 2231.75 & 31.30 & 20.31 & 48.39 \\
\hline
\end{tabular}

\section{Design of experiment}

\section{Design of single curing agent immobilization experiment}

Soils samples $(50 \mathrm{~g})$ were placed in the beakers $(100 \mathrm{~mL})$ and then curing agents (zeolite, sepiolite, vermiculite, and biochar) were added to them, respectively. Batch leaching experiments were conducted at different curing agent concentrations from 0 to $16 \mathrm{~g} \cdot \mathrm{kg}^{-1}$. Then each beaker was added $20 \mathrm{~mL}$ water. The soils dried at room temperature for 2 weeks were sampled by quartering, and then the uniform soils were obtained through a $2 \mathrm{~mm}$ nylon mesh. The soil were screened by 100 meshes, dried and frozen, then placed on the conductive adhesive. The morphological characteristics of the materials were observed by scanning electron microscopy (SEM) (JSM-6510LV). Afterwards, effect of curing agents on $\mathrm{Pb}$ immobilization in soil was tested by Toxicity Characteristic Leaching Procedure (TCLP). And the concentration of lead ion in filtrate was measured by Atomic Absorption Spectrophotometer (AAS) (AA800, America). In this experiment, three parallel samples were used for each data.

\section{Design of GMCAs immobilization experiment}

Soil samples $(50 \mathrm{~g})$ were placed in the beakers $(100 \mathrm{~mL})$ and then added different curing agents according to Table 2. Batch leaching experiments were carried out at curing agent concentration $8 \mathrm{~g} \cdot \mathrm{kg}^{-1}$. Two kinds of curing agent in each group matching were set at three ratios of 1:1, 1:2 and 2:1. Then each beaker was added $20 \mathrm{~mL}$ water. The soils dried at room temperature for 2 weeks were sampled by quartering, and then the uniform soils were obtained through a $2 \mathrm{~mm}$ nylon mesh. Afterwards, effect of GMCAs on Pb immobilization in soil was tested by TCLP. And the concentration of lead ion in filtrate was directly determined by AAS.

Table 2. Twenty-two treatments in the experiment

\begin{tabular}{|c|c|c|c|c|c|}
\hline Number & \begin{tabular}{|c|} 
Single \\
curing agent
\end{tabular} & Number & \begin{tabular}{|c|} 
Group matching curing \\
agents
\end{tabular} & Number & $\begin{array}{c}\text { Group matching curing } \\
\text { agents }\end{array}$ \\
\hline CK & Control & A5 & Zeolite $_{(1)}+$ Sepiolite $_{(1)}{ }^{\mathrm{a}}$ & A14 & Vermiculite $_{(1)}+$ Biochar $_{(1)}$ \\
\hline A1 & Zeolite & A6 & Zeolite $_{(1)}+$ Sepiolite $_{(2)} \mathrm{b}$ & A15 & Vermiculite $_{(1)}+$ Biochar $_{(2)}$ \\
\hline $\mathrm{A} 2$ & Sepiolite & A7 & Zeolite $_{(2)}+$ Sepiolite $_{(1)}{ }^{c}$ & A16 & $\operatorname{Vermiculite}_{(2)}+$ Biochar $_{(1)}$ \\
\hline A3 & Vermiculite & A8 & Zeolite $_{(1)}+$ Vermiculite $_{(1)}$ & A17 & $\operatorname{Sepiolite}_{(1)}+\operatorname{Biochar}_{(1)}$ \\
\hline \multirow[t]{5}{*}{ A4 } & Biochar & A9 & Zeolite $_{(1)}+$ Vermiculite $_{(2)}$ & A18 & Sepiolite $_{(1)}+\operatorname{Biochar}_{(2)}$ \\
\hline & & A10 & Zeolite $_{(2)}+$ Vermiculite $_{(1)}$ & A19 & Sepiolite $_{(2)}+\operatorname{Biochar}_{(1)}$ \\
\hline & & A11 & Zeolite $_{(1)}+$ Biochar $_{(1)}$ & A20 & Sepiolite $_{(1)}+$ Vermiculite $_{(1)}$ \\
\hline & & A12 & Zeolite $_{(1)}+$ Biochar $_{(2)}$ & A 21 & Sepiolite $_{(1)}+$ Vermiculite $_{(2)}$ \\
\hline & & A13 & Zeolite $_{(2)}+$ Biochar $_{(1)}$ & A 22 & Sepiolite $_{(2)}+$ Vermiculite $_{(1)}$ \\
\hline
\end{tabular}

${ }^{\text {aZeolite }}(1)+$ Sepiolite $_{(1)}$, zeolite mixing with sepiolite at a mass ratio of 1:1

${ }^{\text {bZeolite }}(1)+$ Sepiolite $_{(2)}$, zeolite mixing with sepiolite at a mass ratio of $1: 2$

${ }^{c} Z_{\text {Zeolite }}^{(2)}+$ Sepiolite $_{(1)}$, zeolite mixing with sepiolite at a mass ratio of 2:1 


\section{Design of soil column leaching experiment}

Preparation of acid rain

According to the $\mathrm{pH}$ of average rainfall and acid rain monitoring data in Southwest China during the period from 1995 to 2003 (Mei, 2006), the simulated acid rain was prepared. The chemical composition of rainfall was presented in Table 3. Simulated acid rain leaching experiment was carried out by adjusting $\mathrm{pH}$ and compounding the main anion and cation concentrations according to the rainfall characteristics of Southwest China. The acid rain solution (Table 4) was prepared by selecting corresponding salts and calculating its mass on the basis of ion composition and equivalence relation. The solution mixing sulfuric acid and nitric acid was compounded by the rainfall of Southwest China, in which the molar ratio of $\mathrm{SO}_{4}{ }^{2-}$ to $\mathrm{NO}_{3}{ }^{-}$was $3: 1$ (Tang, 2006). And the $\mathrm{pH}$ of rainfall solution was set at 4.7 and was adjusted by adding diluted $\mathrm{NaOH}$ or/and $\mathrm{HNO}_{3}$ solution.

Table 3. The chemical composition and ion content of rain in Southwest China (umol/L)

\begin{tabular}{c|c|c|c|c|c|c|c|c|c}
\hline Ions & $\mathbf{N H}_{4}{ }^{+}$ & $\mathbf{N a}^{+}$ & $\mathbf{K}^{+}$ & $\mathbf{C a}^{\mathbf{2 +}}$ & $\mathbf{S O}_{4}{ }^{\mathbf{2}}$ & $\mathbf{M g}^{\mathbf{2 +}}$ & $\mathbf{N O}_{3}^{-}$ & $\mathbf{C l}^{-}$ & $\mathbf{F}^{-}$ \\
\hline Content & 165.42 & 24.14 & 24.29 & 111.16 & 145.09 & 13.44 & 51.63 & 38.07 & 22.26 \\
\hline
\end{tabular}

Table 4. A variety of salt content in acid rain $(\mathrm{mg} / \mathrm{L})$

\begin{tabular}{c|c|c|c|c|c|c}
\hline Salts & $\mathbf{M g C l}_{2} \cdot \mathbf{6} \mathbf{H}_{\mathbf{2}} \mathbf{O}$ & $\mathbf{C a S O}_{4} \cdot \mathbf{2 H}_{\mathbf{2}} \mathbf{O}$ & $\mathbf{K N O}_{3}$ & $\mathbf{N a F}$ & $\left(\mathbf{N H}_{4}\right)_{2} \mathbf{S O}_{4}$ & $\mathbf{N H}_{4} \mathbf{N O}_{3}$ \\
\hline Content & 2.731 & 19.120 & 2.519 & 0.974 & 10.130 & 0.951 \\
\hline
\end{tabular}

Soil column leaching experiment

Soil samples $(200 \mathrm{~g})$ were placed in the beakers $(500 \mathrm{~mL})$ and then added single curing agents and GMCAs pre-screening. Batch leaching experiments were carried out at curing agent concentration $8 \mathrm{~g} \cdot \mathrm{kg}^{-1}$. The soils after immobilization dried at room temperature for 2 weeks were sampled by quartering, and then the uniform soils were obtained through a $2 \mathrm{~mm}$ nylon mesh. Then soil column leaching experiment was carried out. Soil column leaching apparatus was shown in Figure 1. The soils reacted for a certain time by using intermittent leaching to approach the natural rainfall state. The leachates kept leaching at $8 \mathrm{~h}$ every other day, which was collected for 10 times (a total of $1000 \mathrm{~mL}$ ). Batch soil column leaching experiments were conducted to explore the effects of leaching variables including $\mathrm{pH}$ value, $\mathrm{EC}$ and the concentration of $\mathrm{Pb}$ in soils. Afterwards, the soils after leaching dried naturally at room temperature were sampled by quartering, and then the uniform soils were obtained through a $2 \mathrm{~mm}$ nylon mesh so that determining the fractions of $\mathrm{Pb}$ in soils. The concentration of lead ion in the solution was directly measured by AAS. Moreover, de-ionized water should be used to make the soil column saturated and moist before leaching.

\section{Experimental analytical methods}

Soil $\mathrm{pH}$ value was determined with $\mathrm{H}_{2} \mathrm{O}$ at a 1:2.5 soil solution ratio. Soil organic carbon, total phosphorus and total nitrogen were measured by the Walkley-Black titrations, Digestion-Mo-Sb Anti spectrophotometric method and Kjeldahl method, 
respectively (Bremmer and Mulvaney, 1982; Nelson and Sommers, 1996). The ammonium acetate method was applied to measure cation exchange capacity (CEC) in soils (Rhoades, 1982). The soil digestion method was applied to determine total heavy mental concentration at a volume ratio of 1:2:2 for $\mathrm{HNO}_{3}-\mathrm{HCl}-\mathrm{HClO}_{4}$ mixture (Zhang et al., 2013). The exchangeable, reducible, oxidizable, and residual fractions of $\mathrm{Pb}$ in soils were determined to use the optimized Bureau of Reference (BCR) three-step sequential extraction procedure before and after leaching (Nemati et al., 2011; Pueyo et al., 2008). To determine the amount of $\mathrm{Pb}$ leaching in soil, America Environmental Protection Agency's TCLP was used (U.S. EPA, 1986). The concentration of $\mathrm{Pb}$ in the solution was measured by AAS. And soils after immobilization experiments were photographed by SEM operating at $15 \mathrm{kV}$.

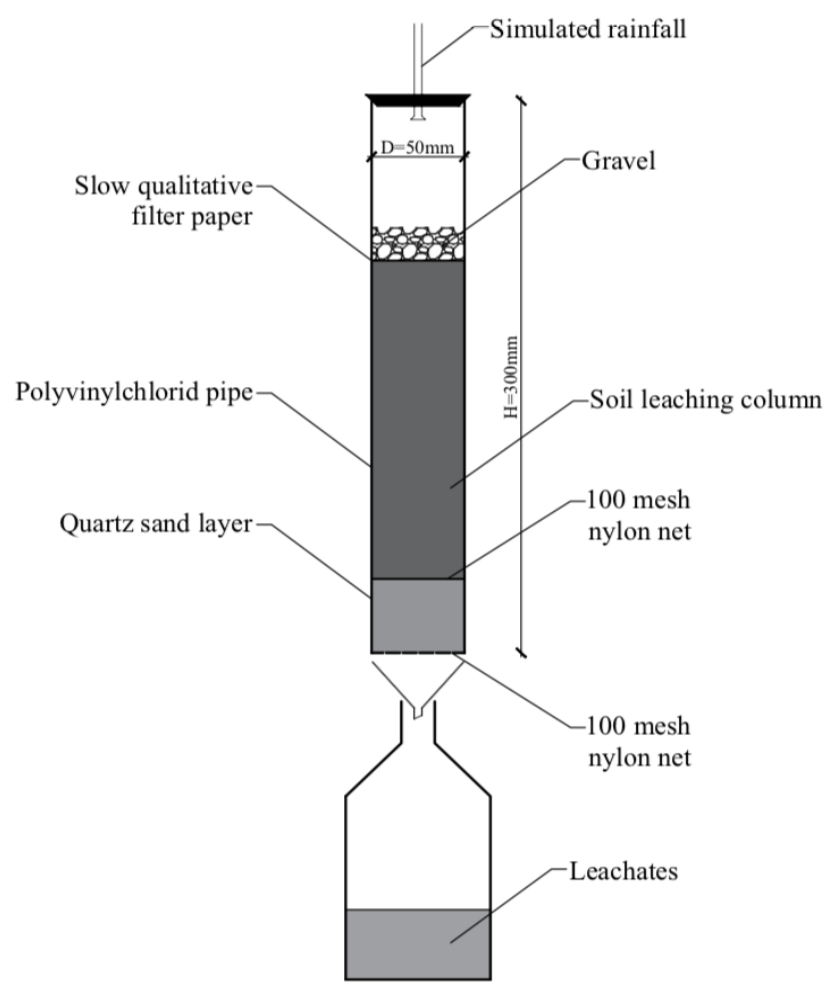

Figure 1. Apparatus of soil column leaching experiment

\section{Statistical analysis}

Statistical data analysis was done with software SPSS Version 19.0. The data were analyzed by Pearson's correlation analysis using a two-tailed test with significance levels of 0.05 and 0.01 .

\section{Results and discussion}

\section{Effect of single curing agent on Pb immobilization in soil}

SEM analysis of soil after adding single curing agent

As shown in Figure 2, the soil samples were photographed by SEM before and after immobilization. It showed that new metal-containing phase was not found after adding 
curing agents in soil by SEM analysis. And the surface particles presented a smoother morphology than the control soil. Therefore, results suggested the dissolution may not be the main immobilization mechanism for heavy metals. Moreover, the reduction of water solubility for heavy metal in soil was mainly attributed to surface ion exchange and co-precipitation, corresponding mineral crystals were formed to make the surface smoother. Similar results also found in the studies of He et al. (2013). It might be due to the addition of curing agents reacting with $\mathrm{Pb}$ in soils to form corresponding lead minerals, which were crystals, so the surface appears smoother. Similar results were also found in Mignardi et al.'s (2012) study. However, there is little difference between different curing agents, of which the mechanism needs to be further explored.

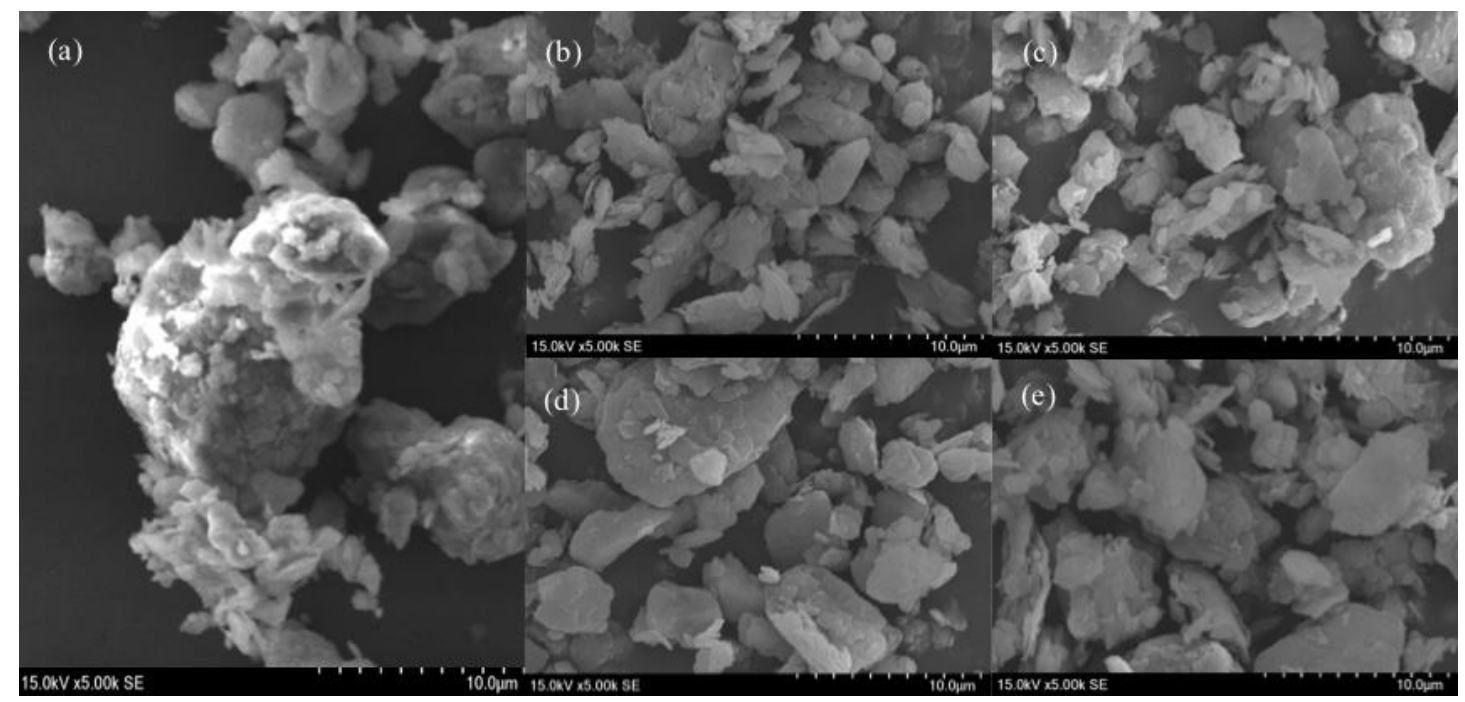

Figure 2. SEM images of the control and the tested soil ( $a$, the control soil; $b$, the soil added $z e o l i t e ; c$, the soil added sepiolite, $d$, the soil added vermiculite; $e$, the soil added biochar)

\section{Effect of single curing agent on soil $\mathrm{pH}$ value}

As shown in Figure 3, the addition of zeolite, sepiolite, vermiculite, and biochar influenced the soil $\mathrm{pH}$ differently. With the concentration of curing agents increasing, soil $\mathrm{pH}$ increased gradually. Soil $\mathrm{pH}$ increases from 6.71 to $7.67,6.95,7.20,6.92$ for four curing agents, respectively, when the concentration of curing agents is $16 \mathrm{~g} / \mathrm{kg}$. It showed that zeolite influenced the soil $\mathrm{pH}$ most in four curing agents, of which the $\mathrm{pH}$ increase was 0.96 . The increase of $\mathrm{pH}$ value was mainly due to the fact that the zeolite was a shelf-shaped silicate mineral of alkali and alkali earth metals, containing a large amount of $\mathrm{Na}^{+}, \mathrm{K}^{+}, \mathrm{Ca}^{2+}, \mathrm{Mg}^{2+}$ ions, which could exchange with $\mathrm{H}^{+}$and $\mathrm{Al}^{3+}$ ions in the soil solution (Chi et al., 2017).

The $\mathrm{pH}$ of soil plays an important role on the remediation of heavy metal contamination. Generally speaking, with the increase of $\mathrm{pH}$, the absorption capacity of heavy metals in soils will enhance. Because heavy metals will form hydroxide precipitates in soil solution as the $\mathrm{OH}^{-}$increases (Begum et al., 2013; Elliott and Brown, 1989). Organic matter and Fe-Mn oxide are considered as the main carrier for heavy metal adsorption in soils, which can bind more strongly with heavy metals, so that reducing the bioavailability and biological activity of heavy metal in soils (Zhou et al., 2010). 


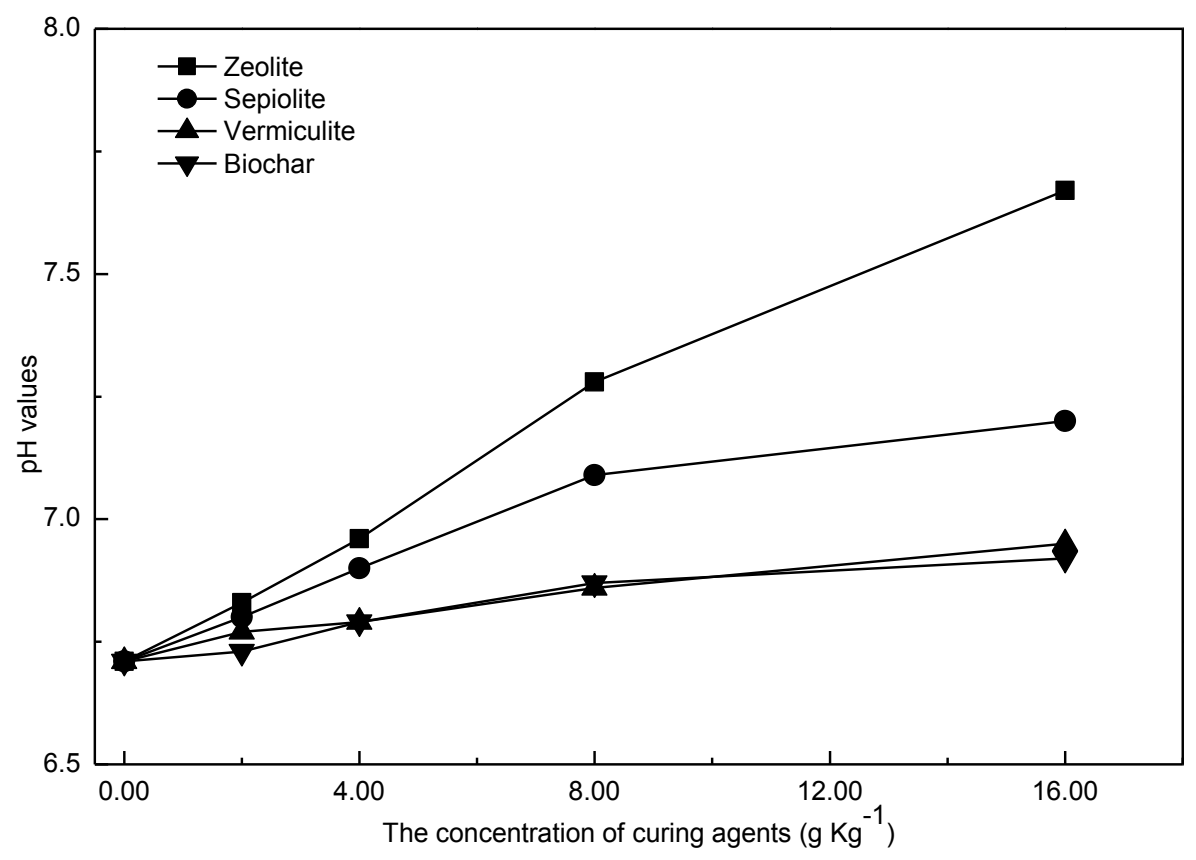

Figure 3. Effect of curing agents on soil $\mathrm{pH}$ value

\section{Effect of single curing agent on Pb immobilization in soil}

As shown in Figures 4 and 5, four kinds of curing agents could reduce the exchangeable $\mathrm{Pb}$ contents and $\mathrm{Pb}$ leaching amounts efficiently. Zeolite, sepiolite, vermiculite and biochar could reduce the exchangeable $\mathrm{Pb}$ contents. When the concentration of curing agents was $16.0 \mathrm{~g} / \mathrm{kg}$, the exchangeable $\mathrm{Pb}$ contents reduced by $93.59 \%, 100 \%, 59.35 \%, 46.91 \%$, respectively. The activity of soil heavy metals depended on the exchangeable fraction (Zhou et al., 2010). Moreover, zeolite, vermiculite and sepiolite could decrease the $\mathrm{Pb}$ leaching amount (Fig. 5). The $\mathrm{Pb}$ leaching amount gradually reduced with further increasing of the curing agent concentration from 0 to $16.0 \mathrm{~g} / \mathrm{kg}$. When the concentration of zeolite, vermiculite and sepiolite all reached $16.0 \mathrm{~g} / \mathrm{kg}, \mathrm{Pb}$ leaching amount reduced by $40.12 \%, 25.50 \%$, $41.28 \%$, respectively.

Compared four kinds of curing agents, zeolite and vermiculite could reduce the exchangeable $\mathrm{Pb}$ contents, which inhibited the activity of $\mathrm{Pb}$ in soils. Moreover, zeolite and sepiolite could reduce $\mathrm{Pb}$ leaching amount effectively. The less leaching amount indicated that only less $\mathrm{Pb}$ took away with the surface runoff, which was less harmful to the environment. Above all, sepiolite was the best for $\mathrm{Pb}$ immobilization in soil, followed by zeolite and vermiculite. Sepiolite could absorb heavy metal ions or complexes with opposite charges in soil to reduce the activity and migration of heavy metals because of its large specific surface area and unique pore structure (Shirvani et al., 2006). Meanwhile, due to the layered chain structure of the crystal, some heavy metal ions would be absorbed into the interlayer crystal structure to become solidified ions so as to achieve solidification (Sun et al., 2012).

Through single factor correlation analysis, it can be found that the amount of four curing agent, soil $\mathrm{pH}$ value and curing effect indicators have a certain correlation. Table 5 shows that soil $\mathrm{pH}$ value is significantly or extremely significantly positively 
correlated with the amount of four curing agents applied. The reduction of exchangeable $\mathrm{Pb}$ contents in soil and the immobilization efficiency are positively correlated with the amount of four curing agents applied. Table 6 shows that soil $\mathrm{pH}$ value is significantly or positively correlated with the reduction of exchangeable $\mathrm{Pb}$ contents in soil and the immobilization efficiency after applying curing agent. To some extent, the increase of soil $\mathrm{pH}$ reduced the bioavailability and migration of $\mathrm{Pb}$ in soil, inhibited the activity of heavy metals, and stabilized $\mathrm{Pb}$ in soil.

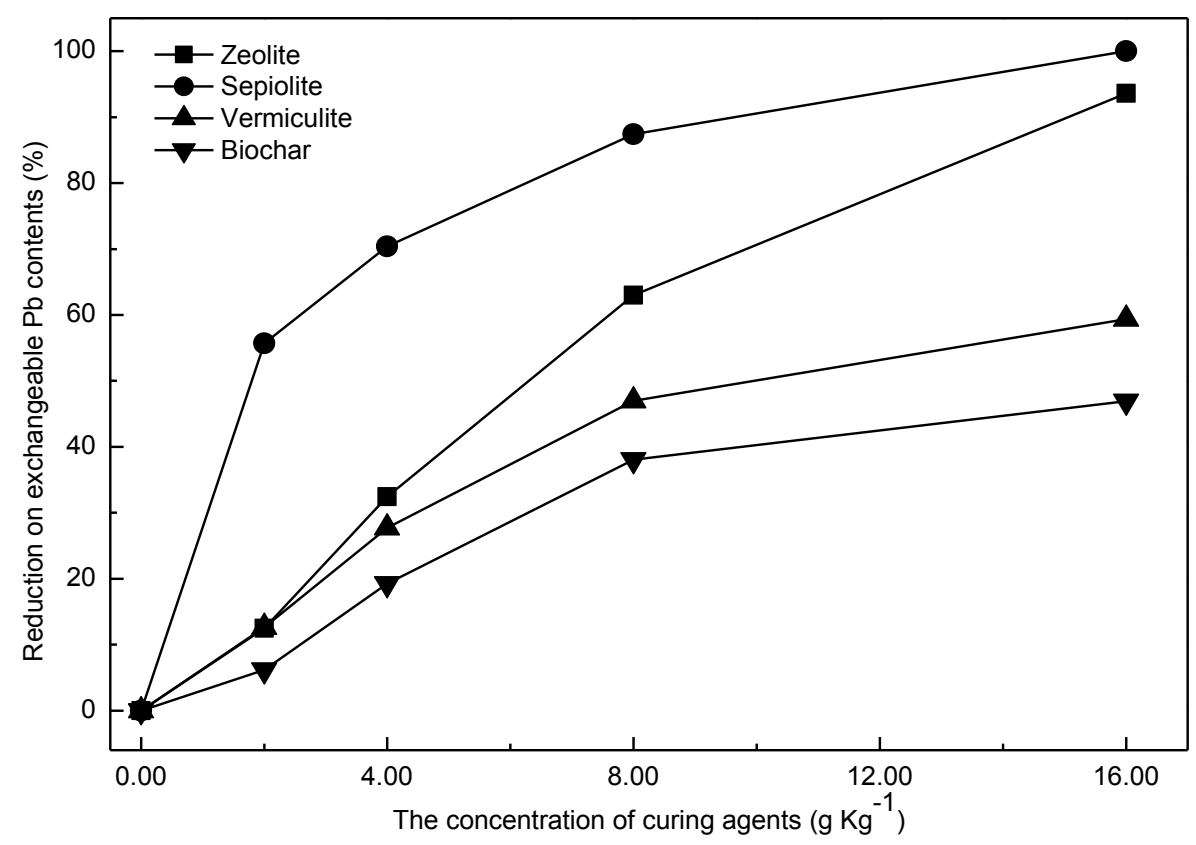

Figure 4. Effect of different curing agents on exchangeable Pb contents in the soil

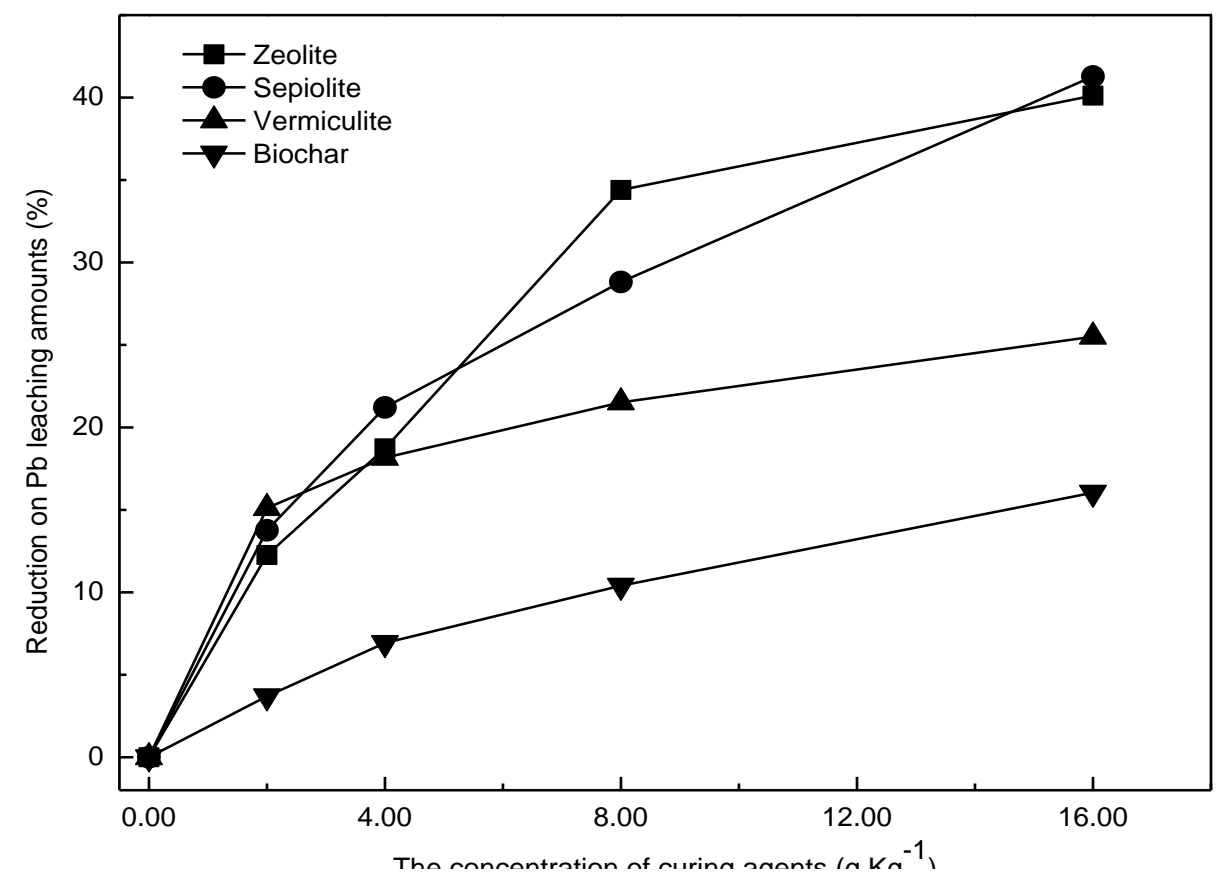

Figure 5. Effect of different curing agents on Pb leaching contents in the soil 
Table 5. Correlation coefficient analysis of dosage of four curing agents and test indexes

\begin{tabular}{c|c|c|c|c}
\hline \multirow{2}{*}{ Number } & \multicolumn{4}{|c}{ Concentration } \\
\cline { 2 - 5 } & Zeolite & Sepiolite & Vermiculite & Biochar \\
\hline $\mathrm{pH}$ & $0.995^{* *}$ & $0.980^{*}$ & $0.987 * *$ & $0.959^{*}$ \\
The reduction of exchangeable Pb contents & $0.982^{* *}$ & 0.825 & $0.947^{*}$ & $0.947^{*}$ \\
Immobilization efficiency & $0.928^{*}$ & $0.949 *$ & 0.814 & $0.977^{* *}$ \\
\hline
\end{tabular}

**Extremely significant correlation $(p \leq 0.01)$

*Significant correlation $(p \leq 0.05)$

Table 6. Correlation coefficient analysis of pH value and curing effect index

\begin{tabular}{c|c|c|c|c}
\hline \multirow{2}{*}{ Number } & \multicolumn{4}{c}{ pH value } \\
\cline { 2 - 5 } & Zeolite & Sepiolite & Vermiculite & Biochar \\
\hline The reduction of exchangeable Pb contents & $0.994 * *$ & $0.902 *$ & $0.976^{* *}$ & $0.999 * *$ \\
Immobilization efficiency & $0.954 *$ & $0.984 * *$ & $0.888^{*}$ & $0.981^{* *}$ \\
\hline
\end{tabular}

**Extremely significant correlation $(p \leq 0.01)$

*Significant correlation $(p \leq 0.05)$

\section{Effect of GMCAs on Pb immobilization in soil}

\section{Effect of GMCAs on soil $p H$ value}

It can be seen from Figure 6 that, compared with the control ( $\mathrm{pH}$ 6.71), single curing agents could increase soil $\mathrm{pH}$, among which the zeolite increased soil $\mathrm{pH}$ most by 0.57 . GMCAs could also increase the soil $\mathrm{pH}$, but the increasing effect was not as good as single curing agents. Among all GMCAs, A5, A13 and A22 possessed a better capacity to increase the soil $\mathrm{pH}$. The $\mathrm{pH}$ was increased by $0.36,0.33$, and 0.30 , respectively. Therefore, GMCAs showed a general effect in adjusting soil $\mathrm{pH}$.

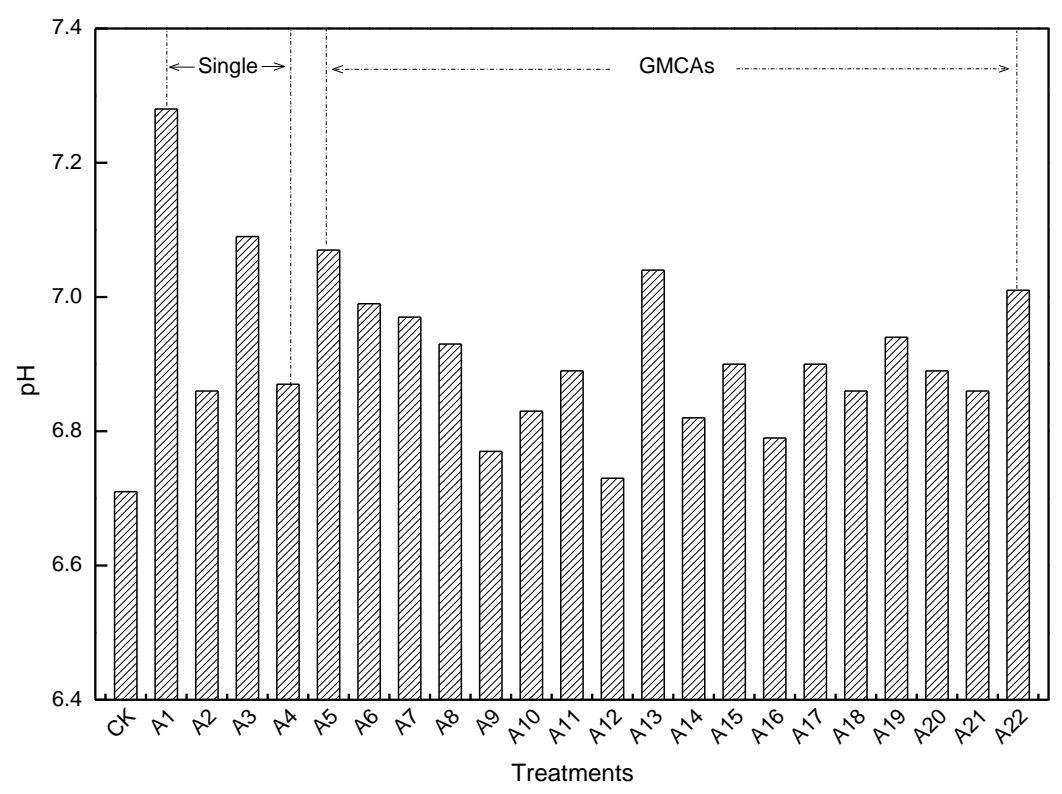

Figure 6. Effect of different treatments on soil pH value 


\section{Effect of GMCAs on Pb immobilization in the soil}

As shown in Figures 7 and 8, when the concentration of GMCAs was $16.0 \mathrm{~g} / \mathrm{kg}$, the various treatments showed different curing efficiency. Besides, different mass ratios of curing agents also performed differently in the same GMCAs. Among all treatments, the GMCAs with a mass ratio of 1:2 or 2:1 for zeolite and sepiolite were the best, and the treatments of these GMCAs decreased the exchangeable $\mathrm{Pb}$ contents in soils by 90.2\%, 86.4\%, respectively. Moreover, A7 and A10 decreased Pb contents effectively in soil leaching solution by $41.4 \%, 42.1 \%$, respectively. Obviously, zeolite mixing with sepiolite at a mass ratio of $2: 1$ could immobilize the soil $\mathrm{Pb}$ effectively. The combination of zeolite and sepiolite had synergistic effect. Similar results were also found in the studies of Liu (2014).

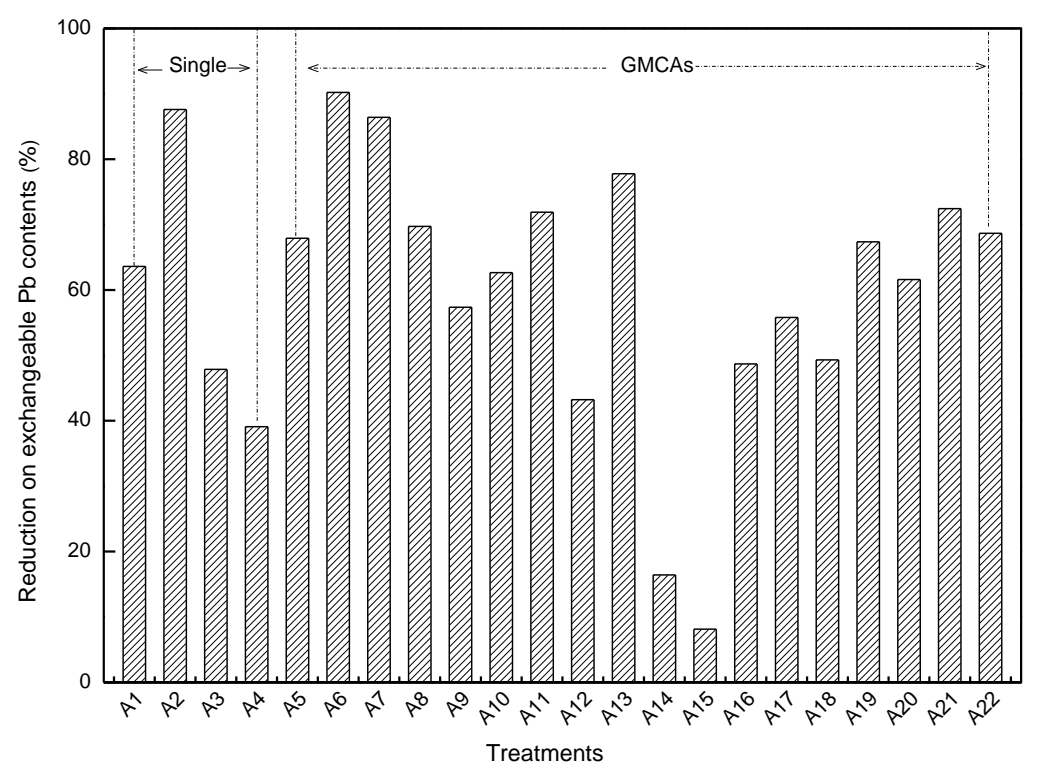

Figure 7. Effect of GMCAs on exchangeable Pb contents in the soil

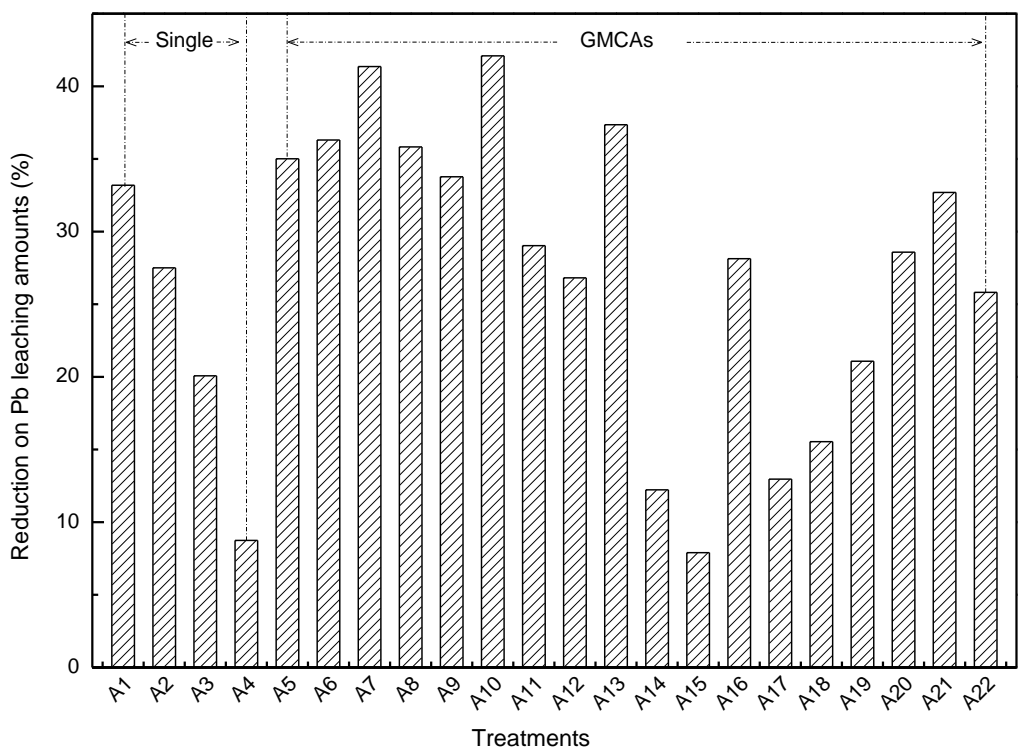

Figure 8. Effect of GMCAs on Pb leaching contents in the soil 
However, compared with the single curing agent, two curing agents at different ratios have different effects on $\mathrm{Pb}$ in soil. Some of them have synergistic effects, while others have antagonistic effects.

\section{The result and analysis of soil column leaching experiment}

\section{Variation of $\mathrm{pH}$ in leachates with leaching times}

Considering the effects of curing agent immobilization preliminarily, soil column leaching experiment was conducted by choosing four single curing agents and four different kinds of GMCAs according to Table 7.

The results of soil leachates $\mathrm{pH}$ from different treatments were shown in Figure 9, which gave the change of the $\mathrm{pH}$ during the soil column leaching experiment. Compared with the $\mathrm{pH}$ of the control, the $\mathrm{pH}$ of other treatments was higher than the original leaching solution. Moreover, the $\mathrm{pH}$ of the leachates first increased and then decreased with the increase of leaching times. The maximum $\mathrm{pH}$ of the leachates was inconsistent in different times, but basically appeared after the fourth leaching. This is mainly determined by the rate of neutralization and exchange reaction between exchangeable base ions and $\mathrm{H}^{+}$input through acid rain. With the continuous reaction of exchangeable base ions and $\mathrm{H}^{+}$input, the $\mathrm{pH}$ of exchangeable base ions begins to decrease slowly after the complete exchange of exchangeable base ions in the midleaching stage. However, because the soil contains a large number of buffer ions, the decrease of pH is relatively small (Zhang et al., 2007; Yu et al., 2001; Fang, 2016; Ma, 2007). In addition, the anions contain in acid rain also coordinate with the hydroxyl groups on the surface of soil particles. Hence, under leaching of leachates, the hydroxyl group enters the solution and consumes $\mathrm{H}^{+}$, which leads to the increase of $\mathrm{pH}$ of soil leachates (Xu et al., 2004). It indicated that the addition of curing agents was beneficial to alleviate the effect of acid rain and improved the soil buffering properties (Yu et al., 2001).

Among the different treatments, the most obviously increasing of $\mathrm{pH}$ was $\mathrm{B} 1$, followed by B6, and the third was B5. The maximum change of $\mathrm{pH}$ could reach 0.69 , which occurring at the $5^{\text {th }}$ time of leaching. For B2, B3, B4, B7 and B8, the increase of $\mathrm{pH}$ was lower than B1, B6 and B5. It showed that the addition of zeolite has the greatest influence on soil $\mathrm{pH}$, which indicated that zeolite increases the cation exchange capacity in soil and adsorbs the hydrogen ions in original solution, thereby increasing $\mathrm{pH}$ of leachates.

Table 7. Nine treatments in the experiment

\begin{tabular}{c|c}
\hline Number & Curing agents \\
\hline $\mathrm{CK}$ & Control \\
$\mathrm{B}_{1}$ & Zeolite \\
$\mathrm{B}_{2}$ & Sepiolite \\
$\mathrm{B}_{3}$ & Vermiculite \\
$\mathrm{B}_{4}$ & Biochar \\
$\mathrm{B}_{5}$ & Zeolite $_{(1)}+$ Sepiolite $_{(2)}$ \\
$\mathrm{B}_{6}$ & Zeolite $_{(2)}+\operatorname{Biochar}_{(1)}$ \\
$\mathrm{B}_{7}$ & Sepiolite $_{(1)}+\operatorname{Vermiculite}_{(2)}$ \\
$\mathrm{B}_{8}$ & Vermiculite $_{(2)}+\operatorname{Biochar}_{(1)}$ \\
\hline
\end{tabular}




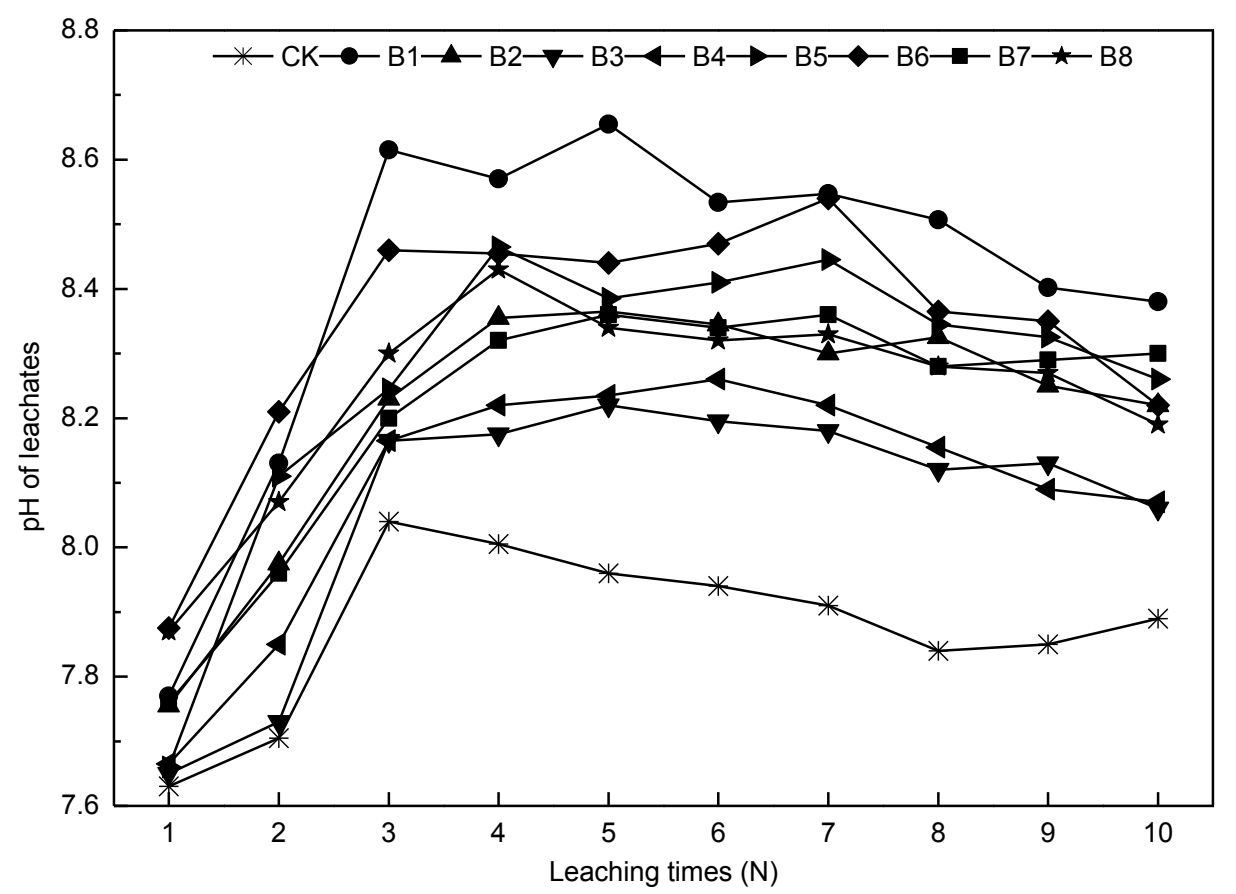

Figure 9. Changes of $p H$ with leaching times in leachates

\section{Variation of EC in leachates with leaching times}

The EC of soil can be used to characterize soluble salt content in soil, and the content of soluble salt in soil shows a great effect on the EC of soil (Sun, 2000). The EC of each treatment was shown in Figure 10 with the leaching of simulated acid rain (pH 4.7). It could be seen that the change of EC in each treatment was approximately the same, and leachates for the first time showed the highest EC. With the increase of the leaching times, the EC rapidly reduced. There was the highest rate at the beginning, and then their concentration was close to equilibrium and remained almost constant with further leaching. It showed that the release of base cation in soil gradually reduced with the increasing of the leaching times, and the initial release quantity was the largest, and then it flattened out. The EC changes can be divided into two stages: rapid decline and slow decline to a steady state. The early stage may be related to the rapid release of various base ions on the soil surface, some soluble oxide particles adsorbed on the soil surface and soluble salts into aqueous solutions. In the later stage, the exchangeable ions in soil become less and less, and the process of slowly releasing and tending to equilibrium is achieved (Zhang et al., 2007; Fang, 2016). At the same time, most of the curing agents are mineral materials. After acid rain leaching, a certain degree of weathering occurs to release the corresponding base ions. Some of them are lost with the leachates, and the other part is adsorbed in the soil, so the conductivity trend tends to balance finally. In addition, acid rain causes a large number of salt-based ions to dissolve, and $\mathrm{H}^{+}$in acid rain replaces salt-based ions in soil colloids. This may also explain that the leachates $\mathrm{pH}$ will decrease with the increase of leaching times (Zhang et al., 2007).

From Figure 10 it could also be seen that the initial EC of each treatment was higher than CK under the leaching of simulated acid rain, indicating that the EC could increase the content of soluble salts and also could reduce the release of base cation after adding curing agents in soils (Rhoades et al., 1990). 


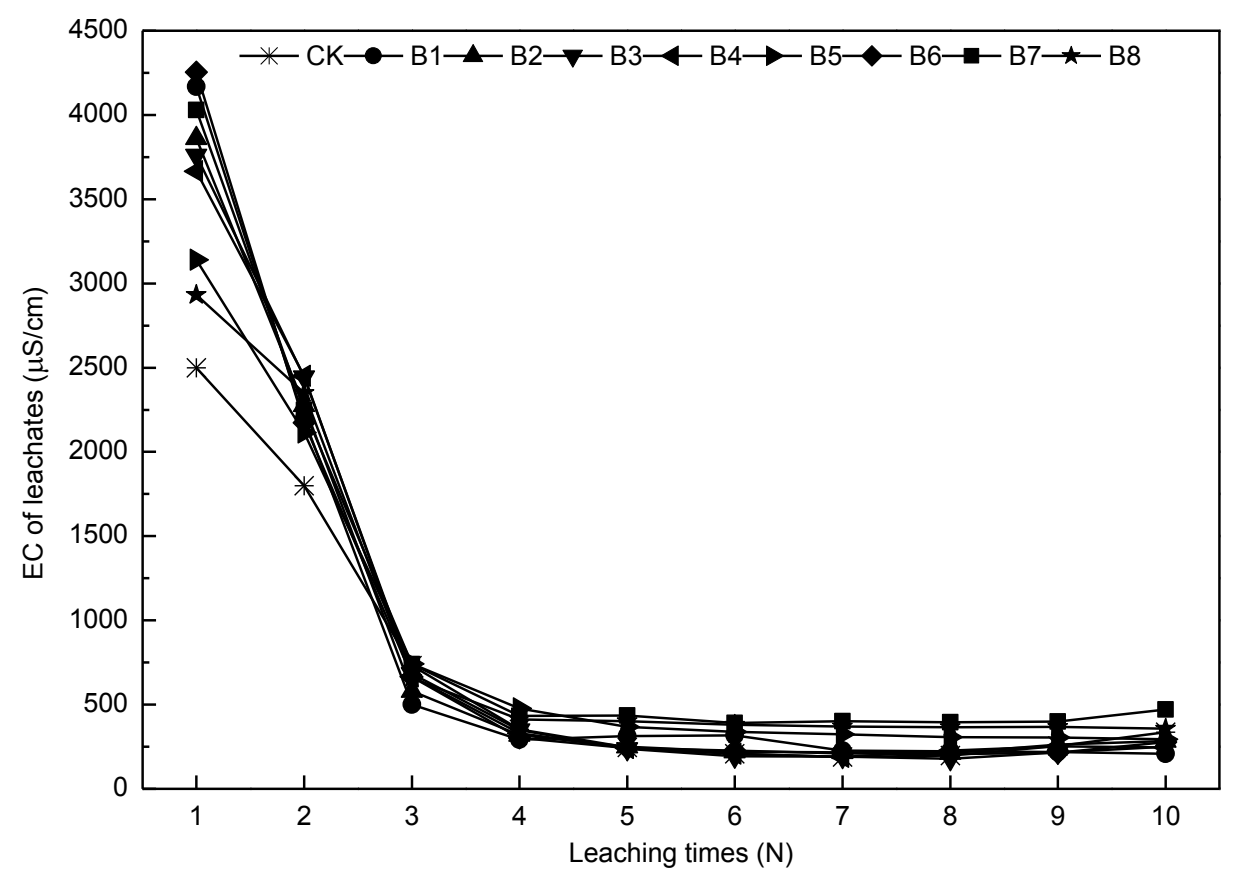

Figure 10. Changes of EC with leaching times in leachates

Correlation analysis was conducted between $\mathrm{Pb}$ content, $\mathrm{pH}$, conductivity and leaching times in leachates under simulated acid rain leaching conditions, and the results were shown in Table 8.

Table 8. The correlation coefficient of leaching times, $p H, E C$ and $P b$ content

\begin{tabular}{c|c|c|c}
\hline The Pb concentration of leachates & Leaching times & $\mathbf{p H}$ & $\mathbf{E C}$ \\
\hline CK & $-0.804^{* *}$ & $-0.725^{*}$ & $0.979^{* *}$ \\
B1 & $-0.838^{* *}$ & $-0.794^{* *}$ & $0.940^{* *}$ \\
B2 & $-0.853^{* *}$ & $-0.872^{* *}$ & $0.943^{* *}$ \\
B3 & $-0.902^{* *}$ & $-0.805^{* *}$ & $0.933^{* *}$ \\
B4 & $-0.881^{* *}$ & $-0.845^{* *}$ & $0.963^{* *}$ \\
B5 & $-0.717^{*}$ & $-0.918^{* *}$ & $0.926^{* *}$ \\
B6 & $-0.758^{*}$ & $-0.848^{* *}$ & $0.995^{* *}$ \\
B7 & $-0.813^{* *}$ & $-0.901^{* *}$ & $0.943^{* *}$ \\
B8 & $-0.650^{*}$ & $-0.879^{* *}$ & $0.907^{* *}$ \\
\hline
\end{tabular}

$* *$ Extremely significant correlation $(p \leq 0.01) . *$ Significant correlation $(p \leq 0.05)$

On the whole, $\mathrm{Pb}$ content in the leachates is significantly negatively correlated with $\mathrm{pH}$. It may be due to the loss of soluble $\mathrm{Pb}$ carbonate in the process of acid rain leaching. With the increase of leaching times, at the beginning, $\mathrm{Pb}$ in the water-soluble and exchangeable states was released quickly due to acid rain leaching, and then $\mathrm{Pb}$ carbonate was also dissolved by $\mathrm{H}^{+}$reaction, leading to loss, so there was a significant correlation (Shi et al., 2013). At the same time, the $\mathrm{Pb}$ content of leachates is significantly negatively correlated with the number of leaching times, and extremely significantly positively correlated with EC. 


\section{Influence of leaching on curing agent immobilization}

The change trend of $\mathrm{Pb}$ concentration in leachates with leaching times was shown in Figure 11 under the leaching of simulated acid rain. It indicated the $\mathrm{Pb}$ concentration significantly reduced with the increasing of leaching time when the leaching time was $\leq 2$. With further leaching, the rate of reduction decreased. The $\mathrm{Pb}$ concentration of B5 decreased most slowly, which decreased from $5.86 \mu \mathrm{g} / \mathrm{L}$ to $0.61 \mu \mathrm{g} / \mathrm{L}$.

Compared with the control $(\mathrm{CK})$, the $\mathrm{Pb}$ concentration of leachates significantly reduced after adding curing agents in soils under the leaching of simulated acid rain. The $\mathrm{Pb}$ concentration of the control was $190.23 \mu \mathrm{g} / \mathrm{L}$. And the maximum concentration of $\mathrm{Pb}$ after adding curing agents was $106.89 \mu \mathrm{g} / \mathrm{L}$. The $\mathrm{Pb}$ content of accumulated leachates from B1 to B8 significantly decreased, and the decreasing rate was $76.03 \%$, $73.01 \%, 44.02 \%, 44.74 \%, 83.97 \%, 79.64 \%, 61.82 \%$ and $55.21 \%$, respectively. The highest decrease rate was $83.97 \%$ resulted from the treatment of zeolite mixed with sepiolite at a mass ratio of 1:2. Curing agent treatment can significantly reduce the leaching of lead in soil under acid rain conditions (Linet al., 2009). Similar results also found in the studies of Tao et al. (2015) and Rao et al. (2013).

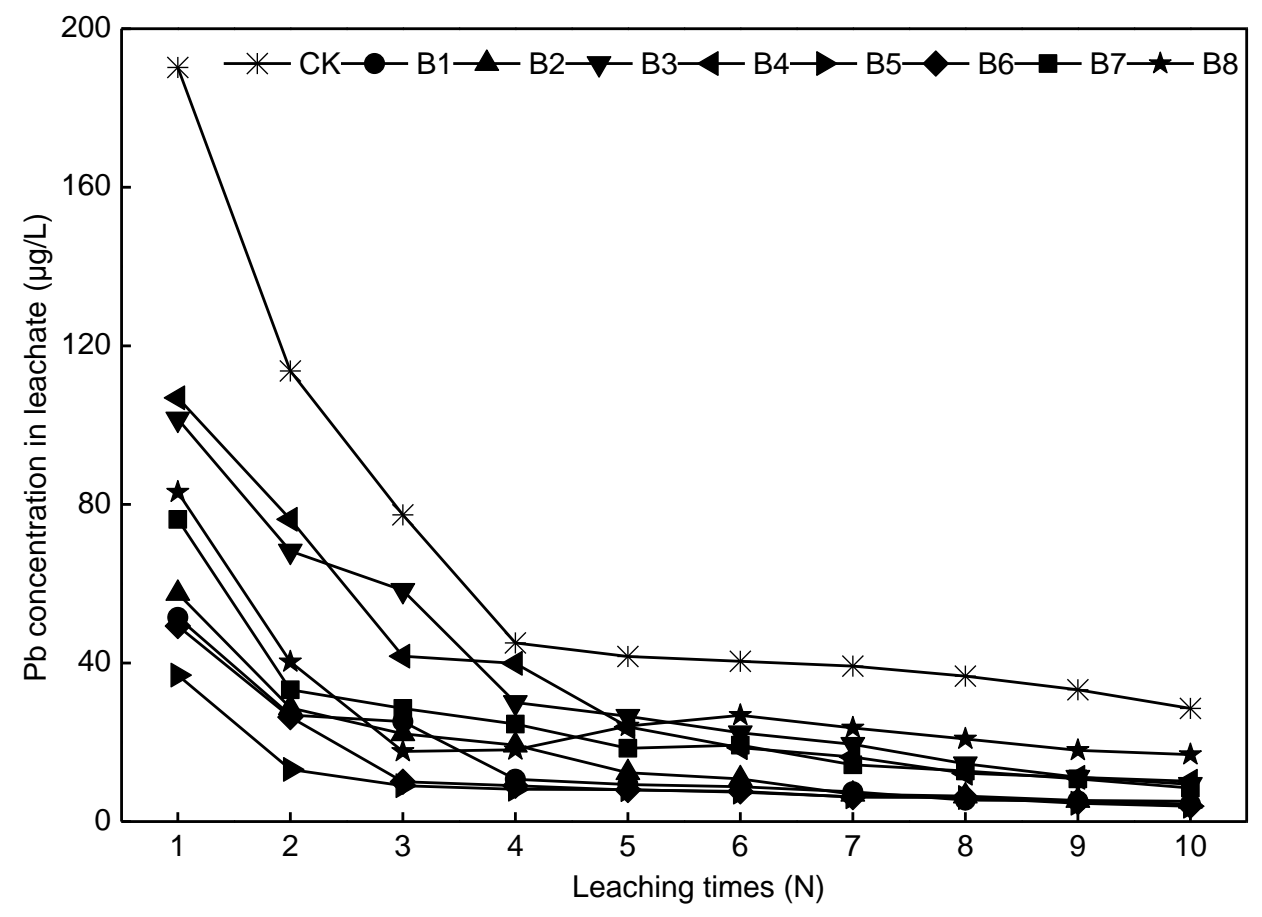

Figure 11. Changes of Pb concentration with leaching times in leachate

\section{Influence of leaching on Pb fractions}

The fractions of $\mathrm{Pb}$ in soil were determined by the $\mathrm{BCR}$ procedure before and after leaching. The changes of $\mathrm{Pb}$ fractions before and after leaching were presented in Figure 12. It indicated that the exchangeable $\mathrm{Pb}$ amount increased and the residual $\mathrm{Pb}$ amount decreased after leaching.

With the addition of different curing agents, the change of reducible and oxidizable $\mathrm{Pb}$ amount was not obvious, of which some increased and some decreased. Our results suggested that the residual $\mathrm{Pb}$ contents gradually transformed into exchangeable $\mathrm{Pb}$, 
reducible $\mathrm{Pb}$ and oxidizable $\mathrm{Pb}$ contents with the increasing of leaching times. In other words, simulated acid rain could activate the fractions of $\mathrm{Pb}$, which increased its bioavailability and migration. However, the addition of curing agents could decrease the leaching $\mathrm{Pb}$ amounts, thus reducing the harm to the ecological environment around the soil (Brown et al., 2004; Geebelen et al., 2003).

The exchangeable $\mathrm{Pb}$ amount of nine treatments (CK and B1-B8) in soil leaching solutions increased by $9.95 \%, 6.69 \%, 6.98 \%, 7.44 \%, 7.81 \%, 4.56 \%, 6.54 \%, 9.19 \%$ and $7.84 \%$, respectively. Among all treatments, the minimum increasing rate was the treatment of B5. That is to say, the activating ability of simulated acid rain was relatively small, namely this treatment posed the minimum potential side-effects to the ecological environment around the soil.

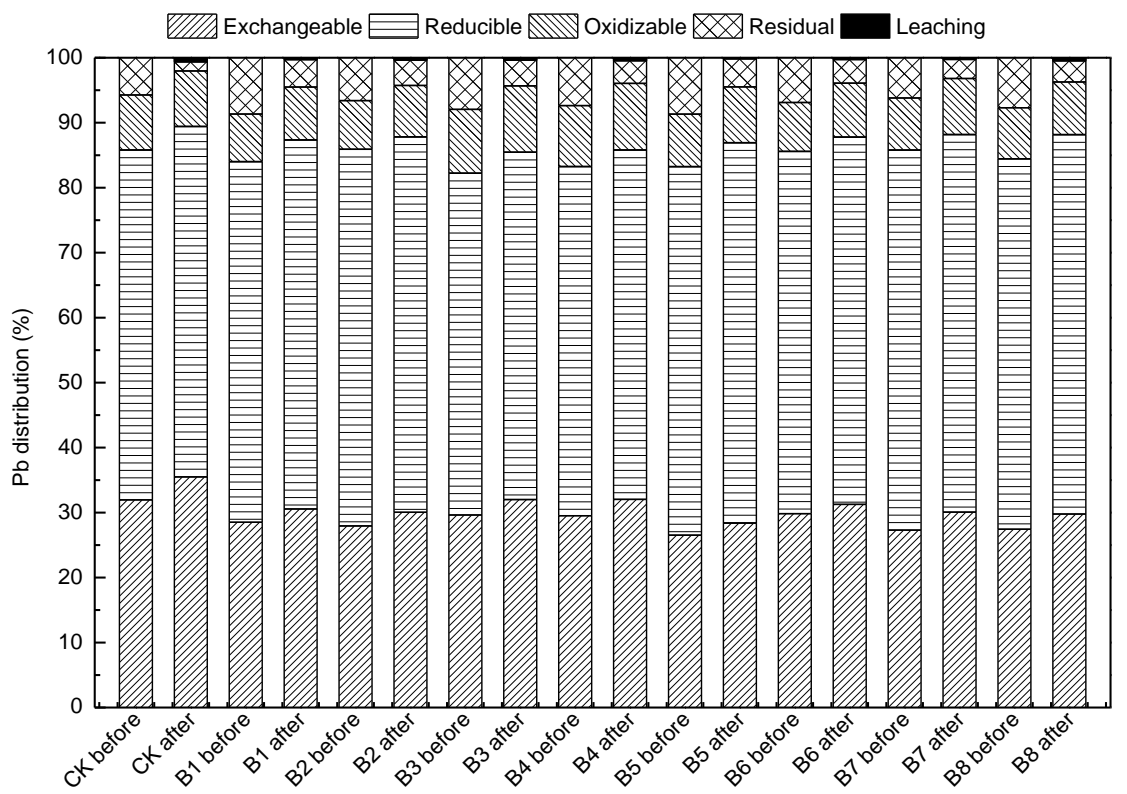

Figure 12. Comparative distribution of $\mathrm{Pb}$ in soil for different treatments before and after leaching

\section{Conclusion}

Four kinds of curing agents showed a better immobilization effect when further increasing of the concentration of curing agents. Compared with the control, the toxicity leaching amount of soils added zeolite, sepiolite, vermiculite and biochar decreased. The decreasing ratios were $40.12 \%, 41.28 \%, 25.50 \%$ and $16.04 \%$, respectively. Moreover, the soil $\mathrm{pH}$ value was significantly or extremely significantly positively correlated with the amount of four curing agents applied. The soil $\mathrm{pH}$ value was significantly or positively correlated with the reduction of exchangeable $\mathrm{Pb}$ contents in soil and the immobilization efficiency after applying curing agent. The treatment of zeolite showed a best effect on reducing toxicity leaching amount of $\mathrm{Pb}$ in soil. Among various GMCAs, zeolite mixing with sepiolite at a mass ratio of 2:1 was the best agent which could immobilize $\mathrm{Pb}$ effectively. Under the leaching condition of $\mathrm{pH} 4.7$, the $\mathrm{pH}$ of leachates generally increased compared with the control, and the EC of leachates presented a falling trend. The $\mathrm{Pb}$ content of accumulated leachates from treatments was decreased, and the highest decrease rate was $83.97 \%$. The residual $\mathrm{Pb}$ contents 
gradually transformed into exchangeable $\mathrm{Pb}$, reducible $\mathrm{Pb}$ and oxidizable $\mathrm{Pb}$ contents with the increasing of leaching times. Moreover, $\mathrm{Pb}$ content in the leachates was significantly negatively correlated with $\mathrm{pH}$, significantly negatively correlated with the number of leaching times, and extremely significantly positively correlated with EC. For all treatments, the treatment of zeolite mixing with sepiolite at a mass ratio of 1:2 showed a best effect on reducing leaching amount of $\mathrm{Pb}$ in soil. Meanwhile, the activating ability of simulated acid rain was relatively small, namely this treatment posed the minimum potential harm to the ecological environment around the soil. That is to say, the addition of curing agents could decrease the bioavailability and migration of $\mathrm{Pb}$, thus reducing the harm to the ecological environment around the soil. In addition, the mechanism of $\mathrm{Pb}$ immobilization and the modification of curing agents need to be future explored.

Acknowledgements. The work was supported by National Key Research and Development Program (2018YFC1802605), Nature Science Foundation of Sichuan Province (2017GZ0383, 2017SZ0181).

\section{REFERENCES}

[1] Amrate, S., Akretche, D. E., Innocent, C., Seta, P. (2005): Removal of Pb from a calcareous soil during EDTA- enhanced electrokinetic extraction. - Science of the Total Environment 349(1): 56-66.

[2] Begum, Z. A., Rahman, I. M. M., Sawai. H. Mizutani, S., Maki, T., Hasegawa, H. (2013): Effect of extraction variables on the viodegradable Chelant-assisted removal of toxic metals from artificially contaminated European reference soils. - Water Air \& Soil Pollution 224(3): 1381.

[3] Bremmer, J. M., Mulvaney, C. S. (1982): Nitrogen: Total. - In: Page, A. L., Miller, R. H., Keeney, D. R. (eds.) Methods of Soil Analysis. Part 2: Chemical and Microbiological Properties. ASA/SSSA, Madison, WI, pp. 595-641.

[4] Brown, S., Chaney, R., Hallfrisch, J., Ryan, J. A., Berti, W. R. (2004): In situ soil treatments to reduce the phyto- and bioavailability of lead, zinc, and cadmium. - Journal of Environmental Quality 33(2): 522.

[5] Cao, S., Duan, X., Zhao, X., Wang, B. B., Ma, J., Fan, D. L., Sun, C. Y., He, B., Wei, F. S., Jiang, G. B. (2015): Health risk assessment of various metal(loid)s via multiple exposure pathways on children living near a typical lead-acid battery plant, China. Environmental Pollution 200: 16-23.

[6] Chi, S., Xu, W., Xiong, S. Wang, W. Z., Qin, Y. L., Zhao, W. Y., Zhang, C. L., Li, Y. H., Li, T., Zhang, J. Z., Xiong, Z. T., Wang, Z. Y., Xie, D. T. (2017): Effect of Nano Zeolites on $\mathrm{pH}, \mathrm{CEC}$ in Soil and Cd fractions in plant and soil at different cadmium levels. Environmental Science 38(4): 1654-1666.

[7] Elliott, H. A., Brown, G. A. (1989): Comparative evaluation of NTA and EDTA for extractive decontamination of Pb-polluted soils. - Water Air \& Soil Pollution 45(3-4): 361-369.

[8] Fang, Z. (2016): Study on Stabilization Characteristics and Stabilization of Soil Heavy Metal Pollution in Lead and Zinc Mining Areas. - China University of Mining \& Technology, Beijing.

[9] Geebelen, W., Adriano, D. C., Lelie, D. V. D., Mench, M., Carleer, R., Clijsters, H., Vangronsveld, J. (2003): Selected bioavailability assays to test the efficacy of amendment-induced immobilization of lead in soils. - Plant \& Soil 249(1): 217-228.

[10] Gupta, D. K., Corpas, F. J., Huang. (2013): Lead tolerance in plants: strategies for phytoremediation. - Environmental Science and Pollution Research 20(4): 2150-2161. 
[11] He, M., Shi, H., Zhao, X. Y., Yu, Y., Qu, B. (2013): Immobilization of Pb and Cd in contaminated soil using nano-crystallite hydroxyapatite. - International Symposium on Environmental Science and Technology. https://doi.org/10.1016/j.proenv.2013.04.090

[12] Lin, H., Shi, W. Shao, H. B., Shao, M. A. (2009): The remediation of the lead-polluted garden soil by natural zeolite. - Journal of Hazardous Materials 169: 1106-1111.

[13] Hwang, A., Ji, W., Kweon, B., Khim, J. (2008): Thephysico-chemical properties and leaching behaviors of phosphatic clay for immobilizing heavy metals. - Chemosphere 70(6): 1141-1145.

[14] Kumpiene, J., Lagerkvist, A., Maurice, C. (2008): Stabilization of As, Cr, Cu, Pb and Zn in soil using amendments - a review. - Waste Management 28(1): 215-225.

[15] Liu, G., Yu, Y., Hou, J., Xue, W., Liu, X. H., Liu, Y. Z., Wang, W. H., Alsaedi, A., Hayat, T., Liu, Z. T. (2014): An ecological risk assessment of heavy metal pollution of the agricultural ecosystem near a lead-acid battery factory. - Ecological Indicators 47: 210-218.

[16] Liu, H. (2014): Effects of Modifier on Heavy Metal Morphology and Remediation Efficiency of Polygonum. - Guangxi Normal University, Guilin, pp. 1-137.

[17] Ma, H. (2007): Morphological Distribution and Leaching Characteristics of Heavy Metals in Municipal Sludge. - Hohai University, Jiangsu, pp. 1-73.

[18] Mcgowen, S. L., Basta, N. T., Brown, G. O. (2001): Use of diammonium phosphate to reduce heavy metal solubility and transport in smelter-contaminated soil. - Journal of Environmental Quality 30(2): 493

[19] Mei, Z. (2006): The Comprehensive analysis on the chemical consistent of precipitation and the formation of acid rain at Chengdu urban area. - Dissertation, Sichuan University, Chengdu, China.

[20] Mignardi, S., Corami, A., Ferrini, V. (2012): Evaluation of the effectiveness of phosphate treatment for the remediation of mine waste soils contaminated with $\mathrm{Cd}, \mathrm{Cu}, \mathrm{Pb}$, and $\mathrm{Zn}$. - Chemosphere 86(4): 354-360.

[21] Nelson, D. W., Sommers, L. E. (1996): Total Carbon, Organic Carbon, and Organic Matter: Laboratory Methods. - In: Sparks, D. L. (ed.) Methods of Soil Analysis. Part 3. SSSA Book Ser. No. 5. SSSA/ASA, Madison, WI, pp 961-1010.

[22] Nemati, K., Abu, Bakar. N. K., Abas, M. R., Sobhanzadeh, E. (2011): Speciation of heavy metals by modified BCR sequential extraction procedure in different depths of sediments from Sungai Buloh, Selangor, Malaysia. - Journal of Hazardous Materials 192(1): 402-410.

[23] Pueyo, M., Mateu, J., Rigol, A., Vidal, M., López-Sánchez, J. F., Rauret, G. (2008): Use of the modified BCR three-step sequential extraction procedure for the study of trace element dynamics in contaminated soils. - Environmental Pollution 152(2): 330-341.

[24] Putra, R. S., Ohkawa, Y., Tanaka, S. (2013): Application of EAPR system on the removal of lead from sandy soil and uptake by Kentucky bluegrass (Poapratensis, L.). Separation \& Purification Technology 102(1): 34-42.

[25] Rao, Z., Zhu, Q. Huang, D. Y., Liu, S. L., Cao, X. L., Ren, X. F., Wang, S., Wang, J. Y. (2013): Effects of sepiolite on cadmium and lead leaching in contaminated red soil under simulated acid rain conditions. - Journal of Soil and Water conservation 27(3): 24-27.

[26] Rhoades, J. D. (1982): Cation Exchange Capacity. - In: Page, A. L., Miller, R. H., Keeney, D. R. (eds.) Methods of Soils Analysis. Part 2: Chemical and Microbiological Properties. Series Agronomy No. 9. ASA/SSSA, Madison, WI, pp 149-157.

[27] Rhoades, J. D., Shouse, P. J., Alves, W. J., Manteghi, N. A., Lesch, S. M. (1990): Determining soil salinity from soil electrical conductivity using different models and estimates. - Soil Science Society of America Journal 54(1): 46-54.

[28] Schwab, A. P., He, Y., Banks, M. K. (2005): The influence of organic ligands on the retention of lead in soil. - Chemosphere 61(6): 856-866. 
[29] Shi, W., Li, H., Du, S., Wang, K. B., Shao, H. B. (2013): Immobilization of lead by application of zeolite: Leaching column and rhizobox incubation studies. - Applied Clay Science 85: 103-108.

[30] Shirvani, M., Kalbasi, M., Shariatmadari, H. (2006): Sorption-desorption of cadmium in aqueous palygorskite, sepiolite, and calcite suspensions: isotherm hysteresis. Chemosphere 65(11): 0-2184.

[31] Suman, Raj. D. S, Aparna, C., Rekha, P., Bindhu, V. M. (2005): Stabilization and solidification technologies for the remediation of contaminated soils and sediments. An overview. - Land Contamination \& Reclamation 13(1): 23-48.

[32] Sun, Y. R. (2000): Experimental survey for the effects of soil water content and soil salinity on soil electrical conductivity. - Journal of China Agricultural University 5(4): 39-41.

[33] Sun, Y. B., Xu, Y. M., Shi, X., Wang, L., Liang, X. F. (2012): The effect of sepiolite on passivation and remediation of cadmium-contaminated red soil. - Journal of Environmental Science 32(06): 1465-1472.

[34] Suzuki, T., Niinae, M., Koga, T., Akita, T., Ohta, M., Choso, T. (2014): EDDS-enhanced electrokinetic remediation of heavy metal-contaminated clay soils under neutral $\mathrm{pH}$ conditions. - Colloids \& Surfaces A Physicochemical \& Engineering Aspects 440(2): 145-150.

[35] Tai, Y., Mcbride, M. B., Li, Z. (2013): Evaluating specificity of sequential extraction for chemical forms of lead in artificially-contaminated and field-contaminated soils. Talanta 107(2): 183-188.

[36] Tang, S. (2006): The studies on the water environmental risk and chemical remediation of heavy mental in urban soils in Guangzhou. - Dissertation. South China Agricultural University, Guandong, China.

[37] Tao, Q., Yao, J., He, S. F., Yang, Y., Li, Y., Liang, Y. (2015): The leaching effect of modified zeolite on $\mathrm{Pb}$ and $\mathrm{Zn}$ in contaminated soil under acid rain was simulated. Journal of Soil and Water Conservation 29(5): 305-308.

[38] Taylor, M. P., Mould, S. A., Kristensen, L. J., Rouillon, M. (2014): Environmental arsenic, cadmium and lead dust emissions from metal mine operations: Implications for environmental management, monitoring and human health. - Environmental Research 135(1): 296-303.

[39] U.S. EPA, Federal Register (1986): Toxicity Characteristic Leaching Procedure (TCLP). - 40CFR, Vol.50, No.286, Appendix 2, Part 268, pp 406-943.

[40] Xu, J., Kleja, D. B., Biester, H., Lagerkvist, A., Kumpiene, J. (2014): Influence of particle size distribution, organic carbon, $\mathrm{pH}$ and chlorides on washing of mercury contaminated soil. - Chemosphere 109: 99-105.

[41] Xu, Z., Xu, D., Liu, G. S., Liu, W. P. (2004): Release characteristics of aluminum, manganese and iron in red soil under acid rain. - Journal of Soil and Water Conservation 18(3): 21-27.

[42] Yu, Y., Ding, A. F., H, Jia., Meng, L. (2001): Effects of simulated acid rain on soil acidification and base ions transplant. - Journal of Nanjing Forestry University 25(2): 3942 .

[43] Zhang, J., Zhang, X., Wang, C. W., Liu, S. P., Liu, Y. H. (2007): Simulated acid rain on soil exchangeable cation migration and its effect on soil acidification in orchards. Journal of Soil and Water Conservation 21(1): 15-17.

[44] Zhang, S., Lin, H., Deng, L., Gong, G. S., Jia, Y. X., Xu, X. X., Li, T., Li, Y., Chen, H. (2013): Cadmium tolerance and accumulation characteristics of Siegesbeckia orientalis, L. - Ecological Engineering 51(2): 133-139.

[45] Zhou, H., Zeng, M., Liu, J., Liao, B. H., Shi, H. (2010): Influence of application $\mathrm{CaCO}_{3}$ on content of $\mathrm{Pb}, \mathrm{Cd}, \mathrm{Zn}$ exchangeable in soil and the cumulative distribution of soybean plants. - Journal of Soil \& Water Conservation 24(4): 123-126. 